\title{
Upwelling nearby the Crimea Western Coast
}

\section{Yu. N. Goryachkin}

Marine Hydrophysical Institute, Russian Academy of Sciences, Sevastopol, Russian Federation e-mail: yngor@yandex.ru

\begin{abstract}
In connection with the problem of the seawater self-purification, the upwelling phenomenon nearby the Crimea western coast is considered in the present article. The observation data on wind and water temperature obtained at the Yevpatoria and Chernomorskoe weather stations as well as the sea surface temperature data derived by the $N O A A-15 / 19$ and MetOp-2 satellites were analyzed. 212 cases of upwelling are identified for the period from 1921 to 2011; most of them fall on July. In the majority of cases, the upwelling duration varied within 2-15 days, but in 20\% of all the cases it lasted 16-30 days. On average, the duration comprised 11.8 days. The average rate of temperature variation in $75 \%$ of the cases observed did not exceed $0.1^{\circ} \mathrm{C} / \mathrm{h}$. The anomalies exceeding $7^{\circ} \mathrm{C} / \mathrm{h}$ were observed in $18 \%$ of the cases; among them there are a few ones worthy of being noted when the temperature dropped by more than $11^{\circ} \mathrm{C}$ (July, 1954 and 1996, and August, 2000). The available multi-year data on upwelling variability demonstrate neither expressed periodicity of the phenomenon nor long-term tendency to its decrease or increase. It is shown that the upwelling phenomenon in the Kalamitsky Bay is determined not only by the Ekman mechanism arising under the influence of the along-coastal wind, but also by the offshore wind effect resulting from the tangential wind stress.
\end{abstract}

Keywords: the Black Sea, Western Crimea, the Kalamitsky Bay, upwelling, water temperature, satellite data.

Acknowledgements: the research is carried out within the framework of the State Order No. 08272018-0004.

For citation: Goryachkin, Yu.N., 2018. Upwelling nearby the Crimea Western Coast. Physical Oceanography, [e-journal] 25(5), pp. 368-379. doi:10.22449/1573-160X-2018-5-368-379.

DOI: $10.22449 / 1573-160 X-2018-4-368-379$

(C) 2018, Yu. N. Goryachkin

(C) 2018, Physical Oceanography

Introduction. Currently, there are several projects involving the construction of the coastal protection structures, yacht marinas and other objects in the coastal area of the Kalamitsky Bay of the Black Sea (Western Crimea). One of the important requirements to be put forward to design solutions is the preservation of the natural self-purification of the coastal waters. The experience of exploitation of shoreline-holding structures on the Crimea southern coast (CSC) showed that there are often stagnation and accumulation of various kinds of debris and pollutants in the spaces between the piers. This significantly reduces the recreational attractiveness of the beaches (Fig. 1).

In the tide-free Black Sea, one of the few natural processes that contribute to the purification of the coastal waters in the summer resort period is upwelling. In Russian this phenomenon is usually called "surge", often without distinguishing between its physical causes.

Concepts of the causes of coastal upwelling in the Black Sea and the water dynamics features in the process of its development are covered well in a number of works based both on theoretical calculations and on numerous field observations and satellite data analysis [1-4]. The largest number of publications is devoted to regional features of the upwelling development and occurrence, for example, 
concerning the Romanian $[4,5]$ and the Turkish coast $[6,7]$ and the eastern part of the sea [6]. To the best extent, the upwelling has been studied in the CSC area. A large number of articles prove this fact; the recently published ones are [9-13]. Upwelling nearby the western coast of Crimea (the Kalamitsky and Karkinitsky bays, the Tarkhankut area) has been much worse studied [14-16]. For example, in [14] the spatiotemporal variability of the upwelling characteristics in the Black Sea northwestern part and nearby the Crimea coast was considered according to satellite observations of 2005-2008 and calculated the phenomenon occurrence frequency for this period. Based on the analysis of satellite images, it is shown that upwelling very rarely spreads along the entire coast of the northwestern part of the Black Sea and Crimea. In this article a unique case on June 12-14, 2005, when the low surface temperature area spread along the entire coast of the northwestern Black Sea and Crimea, was also noted. The results of numerical simulation allowed obtaining a three-dimensional structure of the fields of temperature, salinity, density and velocity of drift currents, reaching $20 \mathrm{~cm} / \mathrm{s}$ at the sea surface. They also showed that upwelling developed evenly along the coast of the northwestern Black Sea and Crimea (except for the southern parts of the Karkinitsky Bay).

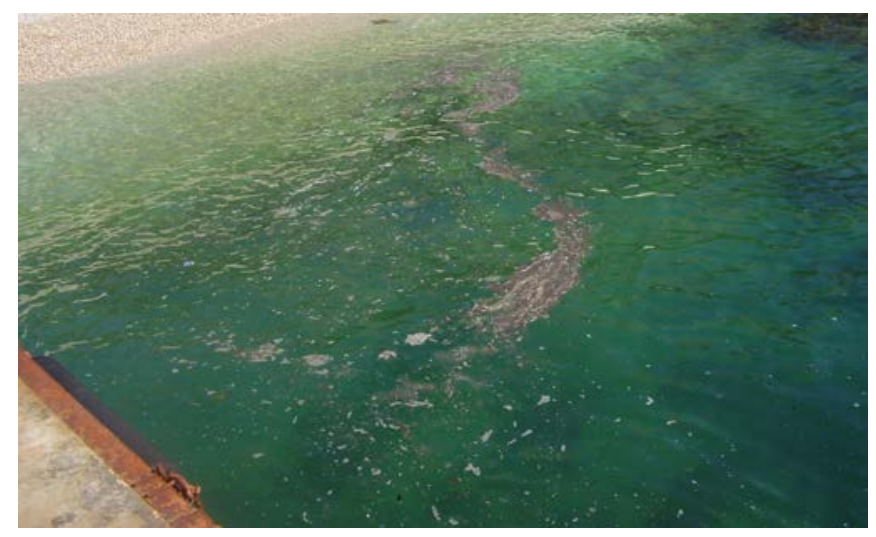

Fig. 1. Accumulation of contaminating admixtures between the piers on the CSC

In [15, p. 56] it is shown that "in the Kalamitsky Bay, the frequency of occurrence of coastal upwelling, identified by sea-surface temperature anomalies, is small (less than one case per year). Upwelling is observed mainly in June and July and is characterized by temperature decrease by $\sim 4-5{ }^{\circ} \mathrm{C}$. Upwelling, accompanied by extreme negative SST anomalies (exceeding $7^{\circ} \mathrm{C}$ in absolute value), is extremely rare”. One of such extreme manifestations of coastal upwelling in September 2007 was described according to a hydrological survey of Marine Hydrophysical Institute (MHI) at the R/V “Experiment”. It is suggested that the main reason was the rise of water, as a result the Black Sea Rim Current jet invasion. It is difficult to agree with the authors of this work, referring the Kalamitsky Bay to the area considered. According to the generally accepted classification, the Kalamitsky Bay includes the water area enclosed between Lukull and Yevpatoriysky Capes. Obviously, the aforementioned article considers the Sevastopol coastal waters. 
In [16], considering the reason for the water surface temperature decrease in the Karkinitsky Bay, the NOAA-15/17 satellite data with a resolution of $1 \mathrm{~km}$ in May - October 2005-2008, the reanalysis data and simulation results applying a three-dimensional numerical model were used. The analysis showed that if in the northern part of the Karkinitsky Bay under the northwestern wind the change in the upper sea layer temperature is actually determined by vertical upward movements of the waters (i. e. upwelling), then the reason for the appearance of cold waters in the southern part of the bay under such a wind is the horizontal advection. Time of the cold water spreading from the upwelling zone throughout the Karkinitsky Bay at a wind speed of about $15 \mathrm{~m} \mathrm{~s}$ is nearly 1 day, and the speed of drift currents in the upper layer is about $20 \mathrm{~cm} / \mathrm{s}$.

Thus, many aspects of the occurence and development of upwelling nearby the Crimea Western Coast, first of all, their statistical characteristics and connection with wind conditions, in contrast to the CSC, have been insufficiently studied. Especially it concerns the Kalamitsky Bay and the water area to the north-west of it (up to Tarkhankut Cape). The purpose of this work is to obtain the mode-statistical characteristics of upwelling in the water area adjacent to this zone and to determine its connection with wind conditions.

The applied data and methods of analysis. The data of long-term regular observations of the wind and water temperature at the Yevpatoria marine hydrometeorological stations (MH) in 1921-2011 and in the Black Sea in 19482011, as well as the $N O A A-15 / 19$ and MetOp-2 satellite observations of the sea surface temperature with a resolution of $1 \mathrm{~km}$ in May - October 2005-2013, carried out 6-8 times a day, are used in the present study. The images were provided by the Remote Sensing Department of Marine Hydrophysical Institute of RAS (http://dvs.net.ru). The presence of upwelling was determined visually from the sea surface temperature maps by the difference between the minimum water temperature in the coastal zone and the temperature of the surrounding waters. If this difference exceeded $3{ }^{\circ} \mathrm{C}$ and remained on 2-3 images, the phenomenon was considered as a manifestation of the coastal upwelling.

In describing the phenomenon, the following notions were used: time of initial development (or formation), intensity, initial rate of water temperature variation and duration. Under the period of formation the difference between the start time of the surge and the appearance of the minimum temperatures was meant. The intensity of upwelling was taken as the difference between the temperature of the start of the surge and the lowest temperature fixed. The surge duration was defined as the time interval between its start and the time when the water temperature reached the initial values. In some cases, the process of new upwelling occurrence obstructed it. Then the termination time of the old upwelling was defined as the start time of the new one. In those cases when the water temperature did not reach the previous values, the end of the process was taken as the time when the water temperature reached quasistationary mode.

In determining the criteria for the selection of upwelling cases, it is important to formalize reasonably the quantitative characteristics of temperature variations. In any case, this is a subjective process, and therefore the result is largely predetermined by such a choice. Thus, in [15], the sample was taken for negative anomalies, exceeding 
in absolute value $4,5,6$, and $7{ }^{\circ} \mathrm{C}$. This is convenient for the development of a calculation algorithm, but in some cases, it does not permit to single out important statistical properties. Therefore, in this work, a time-consuming, but in our opinion, more reasonable procedure was applied. It assumed a visual review of all implementations and the selection of upwelling cases with the subsequent calculation of these characteristics. As a criterion of the case, the value of negative surface temperature anomalies, exceeding $3{ }^{\circ} \mathrm{C}$ in absolute value, was taken.

In the studied area and the period of the year, relatively few stations (about 50) were carried out during the entire observation period. Most of them was made in September 1995 during the MHI expedition on the R/V "Experiment". It does not allow to speak reliably enough of the vertical stratification of temperature and salinity. In this regard, the climatic array of the hydrological data of MHI of RAS with a resolution of $10 \times 15$ miles was analyzed [17]. The six nodes of the array closest to the study area were reduced to one, and from these data the annual course of the $T, S$ characteristics was determined. It showed that the vertical choline structure is characterized by homogeneity in winter period and the greatest development of stratification in spring. The vertical thermal structure in the area under consideration is almost homogeneous in winter, and is most pronounced from May to September. Vertical temperature gradients in the seasonal thermocline are observed in summer, starting at depths of 15-20 m. In a large part of the water area of the Kalamitsky Bay in the summer, the isothermia is observed due to shallow depths, and a layer temperature gradient is observed at individual stations near the bottom. According to $\mathrm{MH}$ Yevpatoria summer temperature, the typical daily temperature variation is up to $0.5^{\circ} \mathrm{C}$.

Results and their discussion. Mode characteristics. In total, in the period of 1921-2011 212 cases of upwelling were picked out on MH Yevpatoria, i. e. on average a little more than two cases occur annually. The largest number falls on July (33 \%), further on decreasing: in June (26\%), August (21\%) and May (16 \%). The smallest number is observed in September, for the entire 90-year period there were only 8 such cases (4\%). In [15], according to the data for 1950-2008, 49 cases were singled out (for the criterion, the value of negative surface temperature anomalies exceeding $4{ }^{\circ} \mathrm{C}$ was taken). Anomalies, exceeding 5, 6 and $7{ }^{\circ} \mathrm{C}$ in absolute value, were observed respectively in 30, 16 and 9 cases. Showing histograms of repeatability, the authors note that coastal upwelling takes place mainly in June and July, which coincides with our data for a longer sample. Discrepancies are noted in the repeatability in May and September. Thus, according to the data of [15], the lowest frequency of occurrence is observed in May and according to our data - in September.

According to $\mathrm{MH}$ Yevpatoria, the characteristic time of upwelling is from 3 to 5 days, which corresponds to the data given in [16]. In most cases, the total duration of upwelling in a particular year (May-September) varied from 2 to 15 days, only in $20 \%$ of cases it ranged from 16 to 30 days. Over the entire observation period, the average total upwelling duration was 11.8 days. Intensity in more than half of the cases is $5-8{ }^{\circ} \mathrm{C}$ (Table). According to [16], typical temperature anomalies are $10{ }^{\circ} \mathrm{C}$; according to the data of the same authors - 3$4{ }^{\circ} \mathrm{C}[14]$.

PHYSICAL OCEANOGRAPHY VOL. 25 ISS. 5 (2018) 
Intensity and average rate of temperature variation during upwelling based on the data of MH Yevpatoria (1921-2011)

\begin{tabular}{c|c|c|c}
\hline Intensity, ${ }^{\circ} \mathrm{C}$ & $\begin{array}{c}\text { Percent of total amount } \\
\text { of cases }\end{array}$ & $\begin{array}{c}\text { Average rate of } \\
\text { temperature variation, }{ }^{\circ} \mathrm{C} / \mathrm{h}\end{array}$ & $\begin{array}{c}\text { Percent of total amount } \\
\text { of cases }\end{array}$ \\
\hline $2.6-5$ & 27 & up to 0.05 & 37 \\
$5-8$ & 55 & $0.05-0.1$ & 38 \\
$8-10$ & 11 & $0.1-0.2$ & 20 \\
over 10 & 7 & over 0.2 & 5 \\
\hline
\end{tabular}

The average rate of temperature variation in $75 \%$ of the cases observed did not exceed $0.1{ }^{\circ} \mathrm{C} / \mathrm{h}$. In $5 \%$ of the cases, this rate was twice as high. In some cases, it exceeded $0.3{ }^{\circ} \mathrm{C} / \mathrm{h}$, which was observed in 1918, 1932, 1997 and 2008. As an example, the event of July 16-20, 2008 is taken. At MH Yevpatoria, upwelling was manifested in the form of two waves of temperature decrease. The first decrease wave (from 23 to $19^{\circ} \mathrm{C}$ ) was observed at the beginning of the day on July 17, the second one (from 20 to $16^{\circ} \mathrm{C}$ ) - at the end of the day on July 17. If the data on the wind only on $\mathrm{MH}$ Yevpatoria is taken into account, then this decrease in temperature cannot be explained. Actually, in the period preceding the water temperature decrease, there was the western wind, but its speed did not exceed $5 \mathrm{~m} / \mathrm{s}$. If the data on the wind on MH Chernomorskoye and satellite images are drawn, it will be clear that in this case the upwelling phenomenon was characteristic of almost the entire water area of the Crimea and adjacent areas. It was caused by steady and strong western winds from July 12 to 16, 2008, as a result, cold waters began to spread east from Tarkhankut Cape and by July 18 occupied the whole Kalamitsky Bay (Fig. 2).
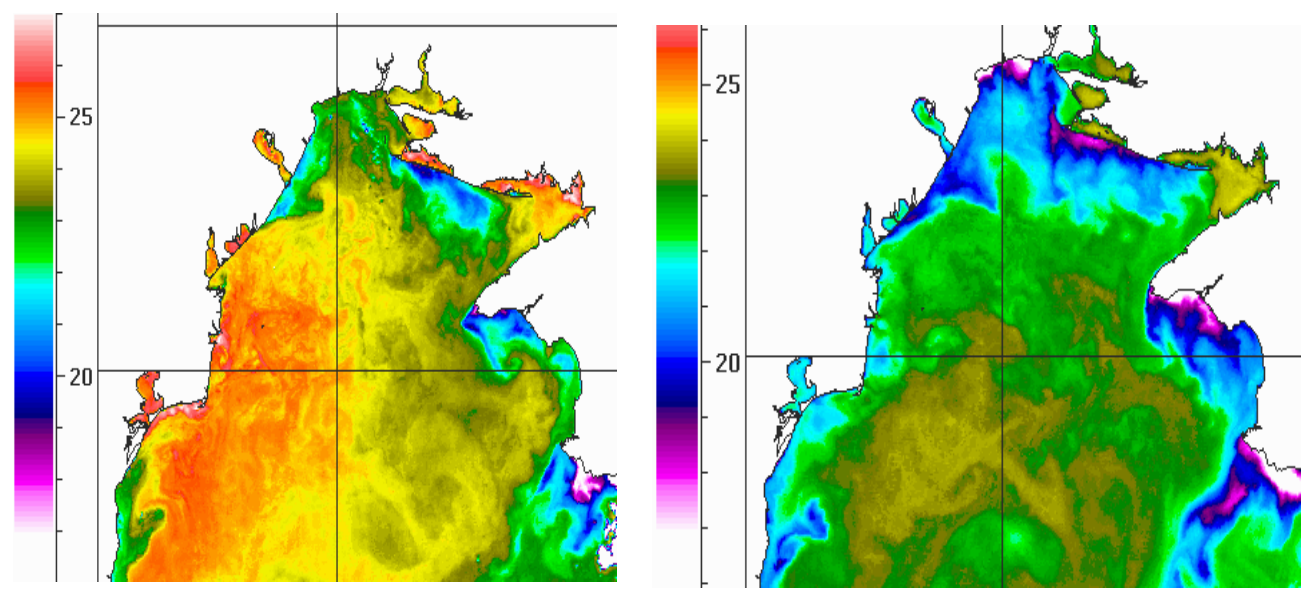

Fig. 2. Surface temperature from the NOAA-15/19 data. On the left -15.07 .2008 , on the right 18.07.2008 (the images are taken from the web-page http://dvs.net.ru)

The surge on the MH Yevpatoria had not already been recorded on July 19, although it was traced by satellite data until July 20. The upwelling, accompanied by extreme negative surface temperature anomalies (more than $11^{\circ} \mathrm{C}$ ), was observed only in three cases. Such unique events were observed in July 1954, 1996 
and in August 2000. So, the surge in 1954 began on July 16, 1954 and was caused by steady stormy western winds. But then, until the end of July, it was supported mainly by the northwestern wind (at a speed of $7-10 \mathrm{~m} / \mathrm{s}$ ). The intensity of upwelling was about $12^{\circ} \mathrm{C}$ (Fig. 3).

Here, it should be noted that on the CSC, the typical intensity is $10-12{ }^{\circ} \mathrm{C}$, reaching in some cases $20^{\circ} \mathrm{C}$. As for the period of formation, for the 1921-2011 in $75 \%$ of cases it was from 1 to 4 days, in $18 \%$ of cases it was from 4 to 10 days and only in $7 \%$ of cases it exceeded 10 days.

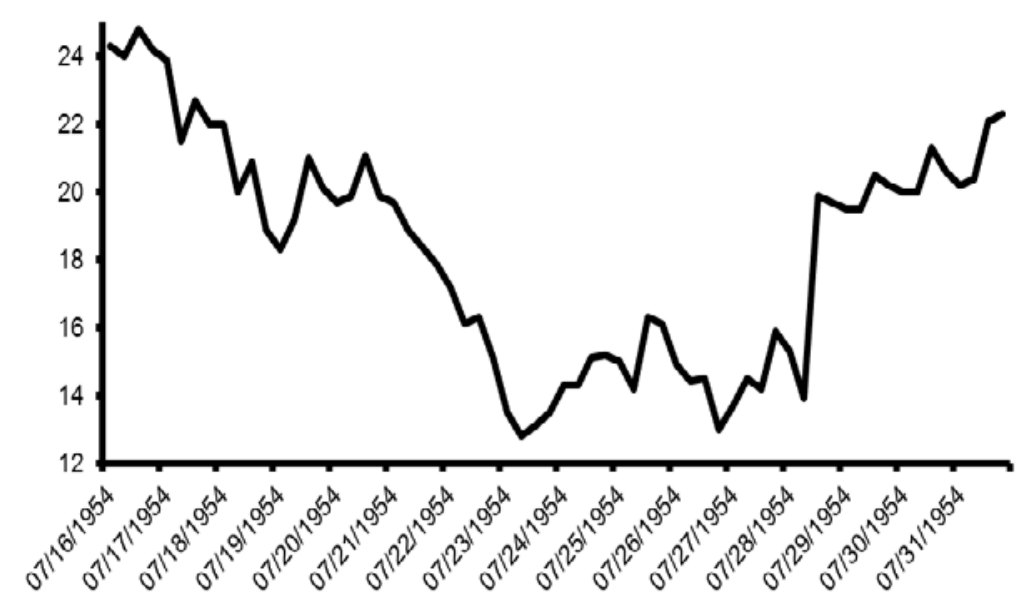

Fig. 3. Temperature variation $\left({ }^{\circ} \mathrm{C}\right)$ at the $\mathrm{MH}$ Yevpatoria on July, $16-31$ based on current data

Interannual variability. 1-2 events of upwelling occur annually (56\% of cases), less often 3-4 (35\% of cases), extremely rarely more than 4 times (6 \% of cases)*. Only once (in 1965) they were not recorded. No statistically significant periodicity in the interannual variability of upwelling events and a reliable trend have been identified.

Relation with wind conditions. In [14], upwelling in the Kalamitsky Bay was singled out into a separate structural zone. The authors note that "a typical water depth of $50 \mathrm{~m}$ in the southern part of the bay reaches $70 \mathrm{~m}$. Therefore, the observed upwelling is characterized as the Ekman one and is formed when exposed to the wind of the northwestern direction" [14, p. 162]. Notice that the depths on the outer side of the Kalamitsky Bay actually are less than $30 \mathrm{~m}$, the isobath of $20 \mathrm{~m}$ passes 7-8 km from the coast (on the CSC - about $400 \mathrm{~m}$ ), and the bay itself refers to the shallow ones. But even if the depths really reached $70 \mathrm{~m}$, then it is hardly possible to argue that the observed upwellings are is only Ekman ones, since even on the deeper CSC shores the surge upwellings caused by short-term strong wind effects are often monitored [13].

\footnotetext{
* Goryachkin, Yu.N., 2016. Upwelling nearby the Crimea Western Coast [Apvelling u beregov Zapadnogo Kryma]. In: The World Ocean: Models, Data and Operational Oceanology. Scientific conference abstracts. Sevastopol, September 26-30, 2016. Sevastopol: FSBSI MHI, p. 145)
} 
To determine the relation of the upwelling phenomena in the Kalamitsky Bay with wind conditions, the following method was used: for each case, immediately before its beginning, the values of wind direction and speed were selected for 3-4 consecutive terms (days). This was done to equalize the importance of each case when calculating the probability characteristics. Since the series contained measurements with a different number of terms, it was impossible to estimate the accumulated wind reliably, which, as is known, along with its direction is crucial for the development of upwelling [1]. It should be noted that the strengthening of the wind in the period preceding the development of upwelling was not always observed. Such cases were not taken into account when calculating (they turned out to be about $30 \%$ ). In general, they can be attributed to the upwelling phenomena that are not associated with local atmospheric effects. One of such cases is shown above in Fig. 3

The entire initial series of water temperature on $\mathrm{MH}$ Yevpatoria was analyzed. After sampling, a continuous series was organized, according to which mode characteristics were calculated. Their analysis showed that the upwelling phenomenon was preceded by the winds of the following directions. The prevailing wind is from the northern direction (36\% of cases), the winds from the western direction have a frequency of $26 \%$, the northwestern one has $20 \%$ and the eastern wind has $14 \%$. The repetition of other directions is very small. On the basis of this analysis, it can be concluded, at a minimum, that the upwelling phenomenon in the Kalamitsky Bay is determined not only by the Ekman mechanism, arising during the action of the alongshore (in our case, the western and northwestern) wind, but also by the purely surge effect due to strong wind from the shore. Of course, such a mechanism is most effective when the thermocline is located close to the surface. On average, the ratio of the Ekman and surge upwelling from this data is close to the ratio of 50: $50 \%$, which follows from the above considerations.

Manifestation in the surface temperature field. Above the statistical characteristics according to the $\mathrm{MH}$ data were considered. Such data make it possible to distinguish the upwelling phenomenon and its development over time quite clearly, but do not allow estimating its spatial scale. According to the satellite data described above, the upwelling repeatability was calculated for each year separately, similar characteristics were calculated according to coastal stations.

One of the problems arising from the satellite information application is the impossibility to carry out a reliable analysis of the surface temperature distribution over long time periods due to the fact that in many images the studied area is covered by clouds. In addition, the MH Yevpatoria location characteristics do not allow attributing water temperature variations to the entire adjacent water area. Therefore, it is difficult to expect a good agreement between the results obtained using satellite information and the results according to the MH data. Nevertheless, in our opinion, quite close results were obtained. So, the extremes are considered, then the maximum number of upwelling was in 2011 ( 7 according to the satellite and 5 according to the contact data), the minimum number was noted in 2010 ( 0 according to the satellite and 1 according to the contact data) (Fig. 4). The difference in the remaining years is from one to three cases, and the number of cases from the contact data is greater than from the satellite one, which is natural for the above reasons. Approximately, the same features can be noted for the 
duration of upwelling (Fig. 4), although its definition according to the MH data was more problematic, which could increase the errors.
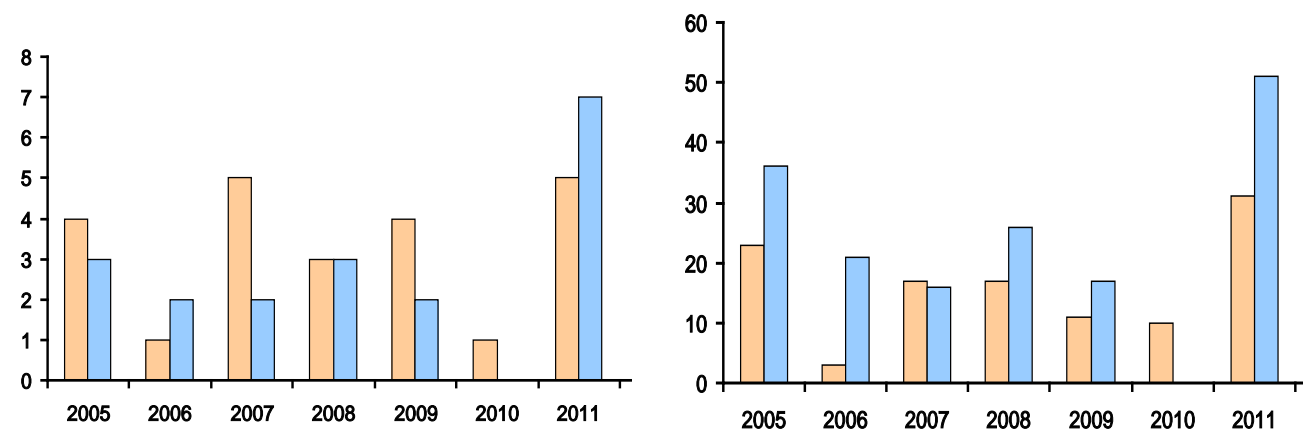

Fig. 4. Interannual variability of the upwelling quantity (left) and its duration in days (right). Blue color marks the satellite data, yellow color - the contact ones

Review of the specific images for the period from 2005 to 2013 and comparison with the wind field revealed two main upwelling development scenarios.

1. The process develops directly in the Kalamitsky Bay or in adjacent areas. At the same time, there is wind from the coast (northern, northeastern and eastern) in the form of a relatively short but strong impulse. Following the data of [1], such upwelling can be attributed to the surge one. As an example, the case of upwelling on July 3, 2006 (Fig. 5) is given.

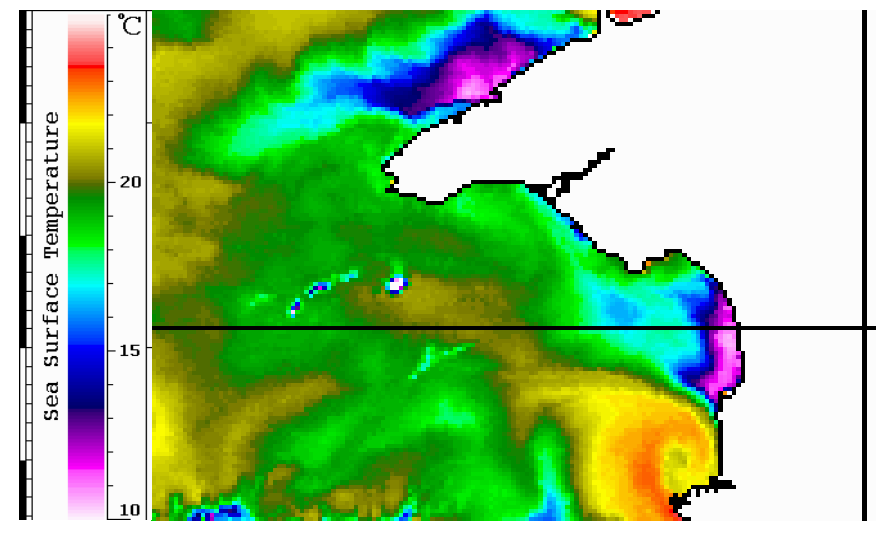

Fig. 5. Sea surface temperature on July 3, 2006 based on the NOAA-17 satellite data

On July 2, there was a steady, strong eastern wind (10-12 m/s) during the day. In the morning, the temperature near the coast began to decrease and within a few hours fell from 23.5 to $19.2{ }^{\circ} \mathrm{C}$. After the wind had weakened, the temperature returned to its initial value during the day. Apparently, it was a case of the surge upwelling. It is usually characterized by rapid development and attenuation of the process. The temperature contrasts are relatively small. In total, for the considered period, 12 such cases were recorded. The only case of this kind of upwelling, in which the currents were instrumentally fixed, was given in [18]. So, on July 12, 1992, the temperature sensor of the MHI 1301 current meter recorded $1 \mathrm{~m}$ from the 
bottom (12 m) near Yevpatoriyskiy Cape, the water temperature decrease from 18.7 to $12.2^{\circ} \mathrm{C}$. Upwelling caused a steady strong (12-15 m/s) eastern wind, which lasted for about a day. The current, previously directed to the southwest, changed its direction in the bottom layer to the northern (toward the coast), and the velocities increased from $5-6 \mathrm{~cm} / \mathrm{s}$ to $12-14 \mathrm{~cm} / \mathrm{s}$. After the termination of the eastern wind, the hydrological situation quickly made a comeback [18].

2. The process begins to develop near Tarkhankut Cape, in a relatively deep coast. In this case, the wind may be western, northwestern and southwestern. After upwelling takes place, cold waters as a result of advection on the surface begin to spread along the coast to the south-east. This can occur in the form of several waves. In some cases, this situation can exist for quite a long time, up to tens of days. The temperature contrasts are substantially higher than for the first type. An example of such an upwelling is shown in Fig. 6.

The upwelling start can be referred to July 20, 2013, when near Tarkhankut Cape a reduced temperature zone was formed, which began to spread along the coast. On July 21 already, the first wave of temperature decrease by $5{ }^{\circ} \mathrm{C}$ was recorded on $\mathrm{MH}$ Yevpatoria (Fig. 7). The second wave of temperature decrease, this time by $9{ }^{\circ} \mathrm{C}$ (up to $14{ }^{\circ} \mathrm{C}$ ), on $\mathrm{MH}$ Yevpatoria was recorded on August 3-11. Thus, upwelling in the area from Tarkhankut Cape to the Kalamitsky Bay with different degrees of localization had existed for more than 20 days.

There were 20 such cases during the considered period. Thus, for a specific period of time (2005-2011), the ratio of the Ekman and surge upwelling was 60: $40 \%$. This is different from the situation in the CSC, where the Ekman upwelling prevails. It should also be noted that the upwelling waters formed in the Tarkhankut area reach the Kalamitsky Bay mainly in the case of strong and prolonged winds of the western direction, which is quite a rare case in summer.

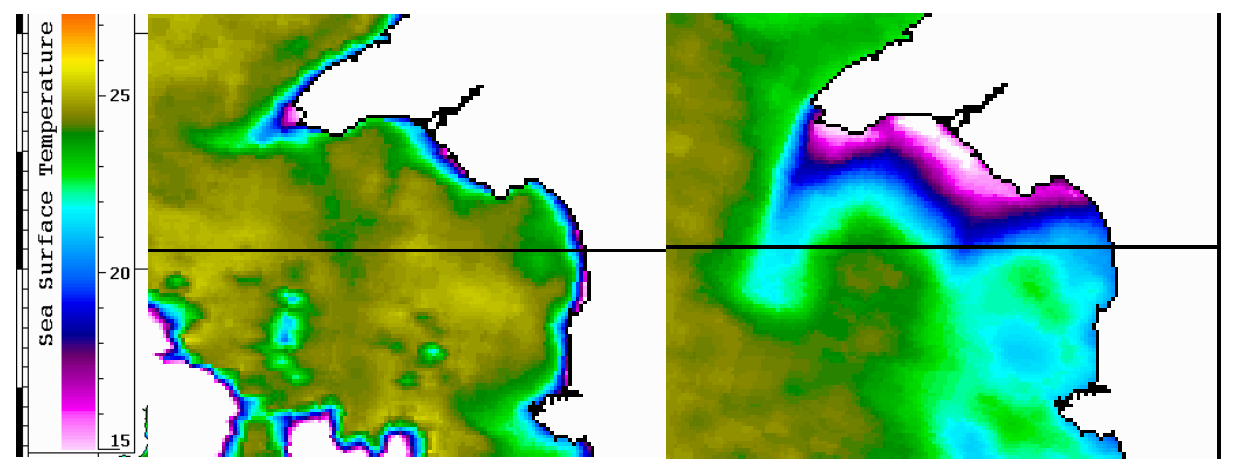

Fig. 6. Sea surface temperature on July 22, 2013 (left) and August 5, 2013 (right) based on the NOAA-17 satellite data

Unfortunately, the lack of hydrological data during the development and destruction of upwelling makes it impossible to find out the horizons cold waters rose from, and compare the theoretical spatial scale of coastal upwelling (baroclinic Rossby radius of deformation) with the observed satellite data. 


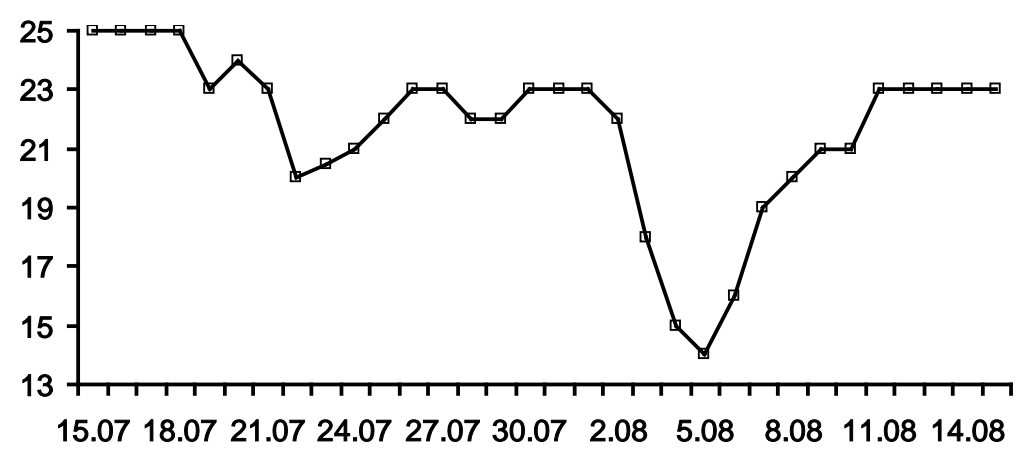

Fig. 7. Sea surface temperature according to the MH Yevpatoria data (July 15 - August 15, 2013)

Conclusion. Based on the aforesaid, the following basic conclusions can be drawn:

- During the period of 1921-2011 MH Yevpatoria monitored 212 upwelling cases. The largest number of cases occur in July, then decreasing: in June, August, May and September.

- In most cases, the duration of upwelling varied from 2 to 15 days, only in $20 \%$ of cases it ranged from 16 to 30 days. The average duration was 11.8 days.

- In $75 \%$ of cases, the upwelling period was from 1 to 4 days, in $18 \%$ of cases it was from 4 to 10 days and only in $7 \%$ of cases it exceeded 10 days.

- The average rate of temperature variation in $75 \%$ of the upwelling cases observed did not exceed $0.1^{\circ} \mathrm{C} / \mathrm{h}$. In $5 \%$ of cases, this rate was twice as high. In 1918, 1932, 1997 and 2008 it exceeded $0.3^{\circ} \mathrm{C} / \mathrm{h}$.

- Anomalies exceeding $7{ }^{\circ} \mathrm{C}$ were observed in 39 cases, of which it is worth highlighting rare cases of temperature decrease by more than $11^{\circ} \mathrm{C}$ (July 1954 and 1996, August 2000).

- In the long-term variability of upwelling events, no pronounced periodicity and a long-term tendency to decrease or increase in their number is not observed. Annually, 1-2 upwelling events occur (56\% of cases), less often 3-4 (35\% of cases), more than four times recorded in six cases.

-The phenomenon of upwelling in the Kalamitsky Bay is determined not only by the Ekman mechanism arising under the alongshore wind action, but also by the purely moving effect caused by strong winds from the coast, the ratio of their repeatability is approximately equal.

\section{REFERENCES}

1. Blatov, A.S. and Ivanov, V.A., 1992. Gidrologiya i Gidrodinamika Shel'fovoy Zony Chernogo Morya (na Primere Yuzhnogo Berega Kryma) [Hydrology and Hydrodynamics of the Black Sea Shelf Zone (on the Example of the South Coast of Crimea]. Kiev: Naukova Dumka, 244 p. (in Russian).

2. Ivanov, V.A. and Mikhailova, E.N., 2008. Apvelling $v$ Chernom More [Upwelling in the Black Sea]. Sevastopol: ECOSI-Gidrofizika, 92 p. (in Russian).

3. Borovskaya, R.V., Lomakin, P.D., Panov, B.N. and Spiridonova, E.O., 2008. Struktura i Mezhgodovaya Izmenchivost' Kharakteristik Pribrezhnogo Chernomorskogo Apvellinga na Osnove Dannykh Sputnikovogo Monitoringa [Structure and Interrannual Variability of Characteristics of Inshore Black Sea Upwelling on Basis of Satellite Monitoring Data]. Issledovanie Zemli iz Kosmosa, (2), pp. 26-36 (in Russian).

PHYSICAL OCEANOGRAPHY VOL. 25 ISS. 5 (2018) 
4. Mihailov, M.-E. and Sandel, G.-V., 2005. The Upwelling Phenomena during Summer on the Romanian Littoral of the Black Sea (Mamaia Bay). In: Proceedings of the Workshop on "Understanding and Modelling the Black Sea Ecosystem in Support of Marine Conventions and Environmental Policies". pp. 15-22.

5. Mihailov, M.-E., Tomescu-Chivu, M.-I. and Dima, V., 2012. Black Sea Water Dynamics on the Romanian Littoral - Case Study: The Upwelling Phenomena. Romanian Reports in Physics, 64(1), pp. 232-245. Available at: URL: https://www.researchgate.net/profile/Maria_Emanuela_Mihailov/publication/286998461_Black _sea_water_dynamics_on_the_Romanian_littoral___Case_study_The_upwelling_phenomena/links/ 56e464a708ae98445c1ef556/Black-sea-water-dynamics-on-the-Romanian-littoral-Case-study-Theupwelling-phenomena.pdf [Accessed: 10 April 2018].

6. Sur, H.I., Özsoy, E. and Ünlüata, Ü., 1994. Boundary Current Instabilities, Upwelling, Shelf Mixing and Eutrophication Processes in the Black Sea. Progress in Oceanography, [e-journal] 33(4), pp. 249-302. https://doi.org/10.1016/0079-6611(94)90020-5

7. Sur, H.I., Özsoy, E., Ilyin, Y.P. and Ünlüata, Ü., 1996. Coastal Deep Ocean Interactions in the Black Sea and Their Ecological Environmental Impacts. Journal of Marine Systems, [e-journal] 7(2-4), pp. 293-320. https://doi.org/10.1016/0924-7963(95)00030-5

8. Silvestrova, K.P., Zatsepin, A.G. and Myslenkov, S.A., 2017. Coastal Upwelling in the Gelendzhik Area of the Black Sea: Effect of Wind and Dynamics. Oceanology, [e-journal] 57(4), pp. 521-530. https://doi.org/10.1134/S0001437017040178

9. Gawarkiewicz, G., Korotaev, G., Stanichny, S., Repetin, L. and Soloviev, D., 1999. Synoptic Upwelling and Cross-Shelf Transport Processes along the Crimean Coast of the Black Sea. Continental Shelf Research, [e-journal] 19(8), pp. 977-1005. https://doi.org/10.1016/S02784343(99)00003-5

10. Goryachkin, Yu.N., 2007. Osnovnye Tendencii Mnogoletnej Izmenchivosti SgonnoNagonnyh Kolebanij Urovnja v Chernom More [Main Trends to Perennial Variability Drived by Level Fluctuations on the Black Sea]. In: MHI, 2007. Ekologicheskaya Bezopasnost' Pribrezhnykh i Shel'fovykh Zon i Kompleksnoe Ispol'zovanie Resursov Shel'fa [Ecological Safety of Coastal and Shelf Zones and Comprehensive Use of Shelf Resources]. Sevastopol: ECOSI-Gidrofizika. Iss. 15, pp. 28-31 (in Russian).

11. Borovskaya, R.V., Lomakin, P.D. and Popov, M.A., 2009. Apvelling v Balaklavskoj Buhte i Prilegajushhih Akvatorijah Chernogo Morja na Baze Sputnikovyh Dannyh [Upwelling in the Balaklava Bay and Ajacent Black Sea Using Satellite Data]. In: MHI, 2009. Ekologicheskaya Bezopasnost' Pribrezhnykh i Shel'fovykh Zon i Kompleksnoe Ispol'zovanie Resursov Shel'fa [Ecological Safety of Coastal and Shelf Zones and Comprehensive Use of Shelf Resources]. Sevastopol: ECOSI-Gidrofizika. Iss. 20, pp. 171-179 (in Russian).

12. Repetin, L.N., Romanov, A.S. and Churilova, T.Ya., 2010. Apvelling v Zone Antitsiklonicheskoy Zavikhrennosti na Shel'fe Yuzhnogo Kryma [Upwelling in the Area of Anticyclone Vorticity on the South Crimea Shelf]. In: MHI, 2010. Ekologicheskaya Bezopasnost' Pribrezhnykh i Shel'fovykh Zon i Kompleksnoe Ispol'zovanie Resursov Shel'fa [Ecological Safety of Coastal and Shelf Zones and Comprehensive Use of Shelf Resources]. Sevastopol: ECOSI-Gidrofizika. Iss. 22, pp. 205-227 (in Russian).

13. Goryachkin, Yu.N. and Ivanov, V.A., 2014. Termohalinnaja Struktura i Dinamika Vod na Chernomorskom Podsputnikovom Poligone [Thermohaline Structure and Dynamics of Waters on the Black Sea Sub-Satellite Polygon]. In: V. A. Ivanov and V. A. Dulov, eds, 2014. Monitoring Pribrezhnoj Zony na Chernomorskom Jeksperimental'nom Podsputnikovom Poligone [Monitoring of the Coastal Zone in the Black Sea Experimental Sub-Satellite Testing Area]. Sevastopol: ECOSI-Gidrofizika, pp. 311-334 (in Russian).

14. Mikhailova, E.N., Muzyleva, M.A. and Polonsky, A.B., 2009. Prostranstvenno-Vremennaja Izmenchivost' Harakteristik Apvellinga v Severo-Zapadnoj Chasti Chernogo Morja i u Poberezh'ja Kryma v 2005-2008 gg. [Spatial and Temporal Variability of Parameters of Upwelling in the Northwestern Black Sea and near Crimea Coast in 2005-2008]. In: MHI, 2009. Ekologicheskaya Bezopasnost' Pribrezhnykh i Shel'fovykh Zon i Kompleksnoe Ispol'zovanie Resursov Shel'fa [Ecological Safety of Coastal and Shelf Zones and Comprehensive Use of Shelf Resources]. Sevastopol: ECOSI-Gidrofizika. Iss. 20, pp. 160170 (in Russian). 
15. Dzhiganshin, G.F., Polonskii, A.B. and Muzyleva, M.A., 2010. Upwelling in the Northwest Part of the Black Sea at the End of the Summer Season and Its Causes. Physical Oceanography, [e-journal] 20(4), pp. 281-293. https://doi.org/10.1007/s11110-010-9084-0

16. Mikhailova, É.N., Polonsky, A.B. and Muzyleva, M.A., 2012. On the Causes of Decrease in the Surface Temperature of Water in the Karkinitskii Bay of the Black Sea. Physical Oceanography, [e-journal] 21(6), pp. 394-400. https://doi.org/10.1007/s11110-012-9131-0

17. Belokopytov, V.N., 2000. Marine Information System in Oceanography and Meteorology of the Black Sea. In: E. T. Balopoulos, G. Chronis, E. Lipiatou and I. Oliounine, eds., 2000. International Conference "Oceanography of the Eastern Mediterranean and Black Sea. Similarities and Differences of Two Interconnected Basins”, Athens, Greece, 23-26 February 1999, abstr. Brussels: European Commission report, pp. 419.

18. Goryachkin, Yu.N., 2008. Pridonnye Techenija v Kalamitskom Zalive [Near-Bottom Currents in Kalamitskiy Bay]. In: MHI, 2008. Ekologicheskaya Bezopasnost' Pribrezhnykh i Shel'fovykh Zon i Kompleksnoe Ispol'zovanie Resursov Shel'fa [Ecological Safety of Coastal and Shelf Zones and Comprehensive Use of Shelf Resources]. Sevastopol: ECOSIGidrofizika. Iss. 17, pp. 258-264 (in Russian).

About the author:

Yuriy N. Goryachkin - Leading Research Associate, Shelf Hydrophysics Department, FSBSI MHI (2 Kapitanskaya St., Sevastopol, 299011, Russian Federation), member of the Sea Coasts Working Group of RAS Council on the World Ocean, Dr.Sci. (Geogr.), ORCID ID: 0000-00022807-201X, ResearcherID: I-3062-2015, yngor@yandex.ru

The author has read and approved the final manuscript.

The author declares that he has no conflict of interest. 